\title{
Současnost starých otázek
}

\section{Topicality of Old Questions}

\author{
Josef Krob
}

Je filosofie a metodologie vědy použitelným nástrojem, nebo je to jen ex post deskripce minulých událostí z dějin vědy? Je možné v této deskripci najít poučení, nebo dokonce návod pro rozhodování v současných otázkách? Na několika prríkladech ad hoc hypotéz z dějin vědy, na pojetí zejména kategorie hmoty a vybraných historických souvislostech se autor snaží ukázat rozporuplnost a problematičnost obecných metodologických principů a návodů a obtížné překonávání mimovědeckých předpokladů vstupujících do hry při formování vědeckých teorií.

\section{Problém užití pojmu hmota}

Pojem hmota se již nějakou dobu zdál být dobře zafixovanou součástí ontologických koncepcí, a pokud se někdo zajímal o jeho definici, byl odkázán spíše na dějiny filosofie než do žhavé současnosti vědy. Moderní přírodověda odmítala ideologizaci hmoty, jak to nabízela např. marxistická filosofie, a pracovala s tímto pojmem velmi účelově a samotný výraz hmota se běžně užíval v několika významech.

I dnes se poměrně často setkáváme s použitím výrazu hmota ve smyslu, který nese jasné stopy dědictví newtonovské fyziky. Pro klasickou fyziku bylo materiální těleso charakterizováno kromě rozměrů zejména hmotností. Hmotné těleso, hmota a hmotnost splývaly v jedno a až do konce 19. století, do objevu radioaktivity, to nečinilo žádné praktické ani teoretické potíže. $S$ radioaktionim rozpadem by se podle mechanicko-materialistického paradigmatu rozpadala $i$ hmota. Pokud bychom totiž setrvali spolu s tímto paradigmatem v tom, že hmota je hmotnost, máme problém. Při radioaktivním 
rozpadu se sice zachovává elektrický náboj, počet nukleonů, hybnost i energie, avšak součet hmotnosti vzniklých prvků je menší než hmotnost atomů před rozpadem. Část se přeměnila v záření, tedy - „hmota/hmotnost se ztratila“. A tak se materialismus musel vypořádat s útokem vedeným pod standartou s nápisem „hmota mizí“ a na místo, které měl svým odchodem ze scény uvolnit, již čekal energetismus. Materialismus však ve 2. polovině 19 . století již nebyl jediným homogenním systémem, vedle mechanické se rodila dialektická verze, a nakonec právě ta starší, která nedělala rozdíl mezi hmotou a hmotností, byla (i z dalších důvodů) obětována a hmota rozšíríila svưj význam i na energii. Od té doby se situace ustálila, teoreticky je obsazení pojmů hmota, hmotnost, látka a energie víceméně jasné, teoreticky jsou všichni srozuměni s tím, že hmotnost je jednou z charakteristik hmoty určujících míru setrvačných/gravitačních účinků a že je užitečné rozlišit i další koncepty hmotnosti (klidová, relativistická), že dalšími charakteristikami hmoty jsou pak např. energie či elektrický náboj a podle toho můžeme ve zkratce mluvit o látce a záření. Ovšem setrvačnost myšlení a jazyka nadále způsobuje, že se setkáváme se s tvrzeními o tom, jak „hmota“, „hmotné hvězdy“ apod. zakřivují prostor, přičemž by pravděpodobně bylo srozumitelnější a určitě by více odpovídalo uvedeným charakteristikám užití výrazu hmotnost.

\section{A co antihmota?}

Podobná, možná o něco složitější situace nastala s užíváním výrazu „antihmota“. Část problémů je napovězena už v okamžiku, kdy si všimneme různých definicí samotného pojmu. Antihmota bývá vymezována takto: a) je to látka z antičástic, b) je to část hmoty, která je tvořena antičásticemi, c) její částice se od hmoty liší zejména opačným elektrickým nábojem nebo nějakou další charakteristikou (spinem). ${ }^{1}$ Podstatné je to, co všechny definice spojuje - opačný elektrický náboj nebo některá další charakteristika částice, přičemž ostatní vlastnosti a projevy jsou shodné s hmotou, resp. s částicemi hmoty. Je tedy zřejmé, že výraz „antihmota“ v tomto kontextu není protikladem vůči „hmotě“ ve významu historicko-filosofickém, ale představuje látku specifických vlastností, které se nejlépe charakterizují předponou anti-, a že tedy pravděpodobně adekvátnějším výrazem by byla „antilátka“. Nicméně

1 SUTTON, Christine. Antimatter. In Encyclopaedia britannica [on-line, cit. 8. 6. 2017]. Dostupné z 〈https://www.britannica.com/science/antimatter>. 
v užívání převažuje výraz antihmota, at̉ už je to proto, že uživatelé nemají obvykle na mysli metafyzické významy nebo, aniž by o to vědomě usilovali, vyjadřují tak i jistou nedostatečnost celého dělení na hmotu, látku, energii (pole) a nedostatečnost (ve smyslu neúplnosti či historické podmíněnosti) samotných definicí hmoty. I když při vymezení částice/antičástice převažuje určení pomocí elektrického náboje, není jediné. Jak už bylo naznačeno, antičástice mohou být určeny také opačným spinem, obecně kvantovým nábojem (elektrický náboj je základním kvantovým nábojem). Naše polární vidění světa, které je docela dobře použitelné v makrosvětě, ze kterého je ostatně také odvozeno, naše snaha vidět svět v intencích bud'-anebo, subjekt-objekt, ano-ne, hmota-duch, látka-pole, ve světě podstatně odlišných rozměrů přestává být tak jednoduše použitelné, ztrácí svou informativnost. Výraz hmota se svými ne zcela jasnými významy se tak docela dobře do této situace hodí.

\section{Hmota jako zástupný pojem?}

Výsledkem však je, že hmota se stále častěji stává zástupným pojmem podobně, jak to známe z běžného jazyka, kdy pro cokoli beztvarého, momentálně neidentifikovaného, použijeme právě toto slovo. Hmota se stává nálepkou pro cosi, o čem mám jedinou znalost nebo alespoň anticipaci, a to znalost, že jde o cosi materiálního. Hmotou tak může být pro kuchaře těsto blíže neurčeného složení, tvárný materiál pro sochaře, cokoli, co gravitačně působí, zase pro fyzika. Soudobá kosmologie tento trend ještě posiluje. Kosmologie byla sice po dlouhá staletí spekulativní metafyzickou disciplínou, fyzikální disciplínou se stala teprve na počátku 20. století s obecnou teorií relativity, a tak bychom možná očekávali větší pochopení nebo alespoň jakousi setrvačnost, pokud jde o užití „hmoty“. Moderní fyzikální kosmologie se však od své metafyzické minulosti odřízla poměrně radikálně, alespoň pokud jde o pojmovou výbavu. ( ̌̌ada metodologických otázek kosmologie však nese stopy její minulosti dodnes, např. nejrůznější principy - kosmologický princip, princip kosmologické unikátnosti, princip extrapolovatelnosti, antropický princip.)

Co tedy znamená, když dnešní kosmolog hledá odpověd' na otázky spjaté s „hmotou“? Vrací se k tradičním ontologickým tématům, nebo spíše dává starému výrazu nový obsah? Neopakuje kosmologie staré chyby, když se snaží zabudovat do svých modelů ad hoc vysvětlení v podobě temné hmoty a temné energie a hledá fyzikální obsah těchto „temných“ termínů? Nečeká nás spíše korekce formulace stávajících zákonitostí, nebo dokonce nové paradigma? 
Výraz hmota, jak si jej v posledních desetiletích přivlastnila moderní kosmologie, slouží převážně $\mathrm{k}$ tomu, aby rychle vyjádřil veškerý obsah vesmíru a aby přitom kosmolog nebyl nucen jej př́liš podrobně specifikovat. Fakt (prozatímní) neschopnosti detailnějšího určení začíná dokonce v rozhodnutí o užití termínu hmota převažovat a „hmota“ se používá - podobně jako tomu je v běžném neodborném jazyce - jako zástupný pojem všude tam, kde není zcela jasné, jaké je konkrétní látkové složení dotyčného objektu. Velmi výrazně se to ukazuje v př́ípadě spojení „temná hmota“, kdy nejde již pouze o metaforický příměr, ale o doslovný význam. Tento výraz si kosmologové zvolili pro označení látky ve vesmíru, která by měla být odpovědná za gravitační efekty, jež není možné uspokojivě vysvětlit svítící hmotou (či hmotou detekovatelnou pomocí elektromagnetického záření). Kosmologové se tak vydávají cestou, která v klasické fyzice opakovaně zklamala, ale v moderní - zejména v kvantové mechanice - naopak přináší jedinečné výsledky.

\section{Nový hráč, nebo změna pravidel?}

V situaci, kdy se v př́írodovědě přijme a ustálí nějaké vysvětlení, je každé zjištění, které do něj nezapadá, potenciálně tomuto vysvětlení nebezpečné. Bud' se ukáže nutnost přijmout mezi stavební kameny teorie další nový prvek, nebo bude potřeba pozměnit pravidla, podle kterých se pracuje s těmi stávajícími. Často se pak také hraje o to, zda stávající vysvětlení obstojí jako celek, nebo zda bude nutné je podstatně inovovat či zcela nahradit. Dějiny vědy nabízejí př́klady úspěchů i neúspěchů obou dvou strategií, a nezdá se tak úplně snadné rozhodnout na základě pouhé analogie z dějin vědy, zda současné objevy budou mít za následek zásadnější proměnu či snad dokonce nahrazení obecné teorie relativity, nebo bude do fyzikální rodiny základních entit adoptována nějaká nová s vlastnostmi, které poskytnou žádoucí vysvětlení.

Všimněme si několika podobných situací z dějin přírodních věd. Jedním z prvních, kdo řešil nesoulad pozorování a vcelku vyhovujícího teoretického konceptu, byl bezpochyby Aristoteles. Jeho teorie přirozených míst a pohybů pracovala s dominantním směrem po vertikále a vysvětlovala jej vlastnostmi živlů podílejících se na skladbě těles - tělesa, ve kterých převládaly živly země a voda, byla těžká a směřovala, a pokud jim v tom nic nebránilo, i se pohybovala dolů, tělesa, ve kterých převažovaly živly oheň a vzduch, mírila a stoupala nahoru. Nahoru stoupal i Aristotelův pohled, kde se zarazil na kruhových pohybech nebeských těles. Tento pohyb neodpovídal žádnému z dosavadních živlů, ani 
jejich kombinaci, a tak si Aristotelés vypomohl pátým elementem - éterem, kterému přisoudil potřebné vlastnosti, a získal tak požadované vysvětlení.

Další velmi jemná látka, které jsou připisovány vlastnosti potřebné $\mathrm{k}$ vysvětlení problematického jevu, flogiston, se objevuje na scéně v 18. století v chemických laboratořích, resp. v hlavách chemiků, a pomáhá vysvětlit podstatu hoření. Princip flogistonové teorie je stejný jako v případě éteru - pozorované jevy jsou uspokojivě vysvětleny přítomností a uvolňováním hypotetické látky, která má právě takové vlastnosti, které jsou k explikaci nezbytné.

Zdálo by se, že princip skrytých parametrů či entit bude přijímán velmi zdrženlivě. Jenže pak byl objeven Neptun. V r. 1840 bylo již zřejmé, že dráha Uranu není přesně taková, jaká by měla být podle teorie gravitace. Zachránit úspěšnou teorii bylo možné předpokladem existence dalšího zatím neznámého tělesa, jehož vliv by vysvětlil pozorované pohyby Uranu. A skutečně po přesných výpočtech bylo nové těleso v r. 1846 pozorováno. Podle stejného principu byl posléze hledán Vulkán. Toto těleso mělo vysvětlit pozorované změny oběžné dráhy Merkuru - stáčení jeho perihélia. Vulkán však nikdy objeven nebyl a vysvětlení se dostavilo až s novou teorií gravitace - obecnou teorií relativity. V současnosti je z podobných důvodů hledána planeta Devět, jejíž existence by mohla vysvětlit pohyby těles na drahách za Neptunem.

Tyto momenty z dějin fyziky, chemie a astronomie se tak stávají učebnicovými př́klady, na kterých se demonstruje, jak funguje, či nefunguje ad hoc předpoklad. Fyzika 20. století pak nabízí, zejména v oblasti kvantové mechaniky, celou řadu předpovědí týkajících se existence částic, které „musí“ existovat, aby dobře doplňovaly částicovou stavebnici podle stávajících teorií. Ve valné většině případů se předpovědi dříve či později potvrdily, demonstrují úspěšnost a svědčí pro oprávněnost doplňování teorie dalšími předpoklady, entitami a elementy. Typickým příkladem je předpověd' (1928) a následný objev (1932) pozitronu, ale s jistou dávkou velkorysosti můžeme jako příklad uvádět i další subatomární částice (proton, neutron), jejichž předpokládaná existence vysvětlovala výsledky pozorovaných jevů. Využít však teorii dalších skrytých parametrů pro vysvětlení kvantového systému jako celku a pokus představit ho jako systém klasický, tj. deterministický, k úspěchu nevedlo.

\section{Temná hmota a temná filosofie}

Nové i starší, ovšem opakovaně potvrzované objevy v kosmologii vytvářejí nerozhodnou situaci pro teorii gravitace, obecnou teorii relativity. Nabízí se otázka, 
zda více než stoletá teorie je stále ještě v kondici a zvládne odolávat novým objevům a absorbovat dodatečná vysvětlení, nebo zda je čas na teorii novou.

Když v roce 1933 Fritz Zwicky objevil nesoulad mezi rotací odlehlých kup galaxií a celkovou hmotností galaxií, ${ }^{2}$ nabízely se mu dvě možnosti. Aby uspokojivě vysvětlil fakt, že se ty kupy galaxií při této rychlosti nerozpadnou vlivem odstředivé síly, musel bud' předpokládat existenci další látky (hmoty), která se podílí na výsledném gravitačním působení, ale není pozorovatelná, nebo zapochybovat o platnosti gravitačního zákona v těchto měřících, tedy modifikovat obecnou teorii relativity, která by nadále dobře fungovala v rozměrech podgalaktických, ovšem v rozměrech vyšších řádů by již musela být korigována či podstatněji změněna. Zwicky se vydal cestou předpokladu další, skryté hmoty (hidden matter), později označované spíše jako temná hmota (dark matter).

Přestože to vypadá tak, že většina kosmologů se v současné době účastní pátrání po entitě, která by mohla být temnou hmotou, stále je i dost těch, kteří se k její existenci staví rezervovaně.

Samozřejmě by bylo možné a seriózní všimnout si velkých metodologických úvah v dějinách filosofie a konfrontovat je se současným stavem, ale... Když se probírám dějinami vědy, nedaří se mi nalézt případ, kdy by př́rodovědec postavený před těžký problém ve svém oboru obrátil svou pozornost k filosofii a filosofům a požádal je o pomoc s řešením. Filosofie vědy se dělá ex post, nefunguje jako recept na řešení budoucích problémů. A ani dnes se kosmologové neptají, zda je vhodnější řešit problém temné hmoty v duchu koncepce Feyerabenda nebo spíše vsadit na Lakatosův model, nechat se inspirovat Kuhnem nebo jakýmkoli jiným filosofem, který byl v daném okamžiku zrovna v kurzu, maximálně připomenou Poppera a jeho princip falzifikace, který se stává vědeckým folklórem.

F. Engels sice přírodovědce varoval, že když se nebudou držet té správné filosofie, propadnou nejhorším pověrám a mystice a ocitnou se v zajetí kněžourství, ${ }^{3}$ ale toto varování nenacházelo zejména v řadách „buržoazních“ vědců, kterým bylo určeno, kladnou odezvu. Vědci se ani poté neptali filosofů, co mají dělat, když narazí na problém, nýbrž hledali odpověd' ve svých datech a měřeních. I když se dnešní badatelé nemusejí obávat nařčení z kněžourství

2 EGDALL, Mark. The Remarkable Discoveries of Fritz Zwicky. Decoded Science 2012, July 2 [on-line, cit. 14. 6. 2017]. Dostupné z <https://www.decodedscience.org/the-remarkable-discoveries-fritz-zwicky/15456>.

3 Viz ENGELS, Friedrich. Dialektika přírody. Přeložil kolektiv překladatelů. Redakční spolupráce Kateřina OŠANCOVÁ a Miluše SVATOŠOVÁ. Praha: Svoboda ${ }^{1} 1950$. Velká knihovna marxismu a leninismu, sv. 7, s. 13 . 
nebo nálepky „buržoazního vědce“, neznamená to, že by nikdy, důsledkem jiné motivace, „nepropadali“ filosofii, nenechali se ovlivnit nevědeckými předsudky či mimovědeckými stereotypy. Samotná historie termínu temné hmoty je toho příkladem. Jestliže se zeptáme, proč se o ní mluví tak intenzivně až v posledním desetiletí, když ji F. Zwicky předpokládal již ve 30. letech, vědecký folklór a kuloáry nám nabídnou odpověd’ zcela neexaktní. Zwicky prý byl hrubián a vulgární člověk, který své kolegy a studenty nazýval jen těžko publikovatelnými jmény, a proto nikdo neměl př́liš chuti dostat se do jeho pracovního okruhu. Tak se stalo, že myšlenka temné hmoty nenašla žádného pokračovatele a musela počkat až do 60. let 20. století, kdy se k ní po dalších a přesnějších měřeních vrátila Vera Rubinová. ${ }^{4}$ Tato americká astronomka sice mluvila slušně, ale byla to žena a matka malých dětí, a tak kromě přirozeného vědeckého skepticismu svých kolegů musela překonávat ještě další předsudky, což se jí výrazně podařilo až počátkem 90. let s nástupem dokonalejších pozorovacích technologií.

Ale i když se pokusíme eliminovat evidentní mimovědecké vlivy a budeme brát v potaz pouze vědecké argumenty, pravděpodobně objevíme určité méně zdůvodněné sympatie $\mathrm{k}$ jednomu či druhému řešení. Zrekapitulujme si situaci: Máme prvotní pozorování, jehož výsledek lze vysvětlit a) přijetím předpokladu o existenci další doposud neznámé entity, b) úpravou stávajících zákonitostí, c) zpochybněním pozorování. $\mathrm{Z}$ dějin vědy víme, že hypotézy ad hoc bývají spíše kontroverzním nástrojem, a stejně tak víme, že obě teorie relativity slavily úspěch mimo jiné i proto, že se dokázaly obejít bez nadbytečných entit (STR éteru, OTR např. Vulkánu) a nabídnout elegantnější vysvětlení. A i samotná historie principu relativity a teorie gravitace jsou dějinami překonávání ad hoc hypotéz, které se ukázaly jako neudržitelné.

\section{Je čas na novou teorii?}

Proti tomu stojí skutečnost, že OTR je teorie z doby, kdy nebyly známy galaxie, je zformulována v situaci, kdy je známo v podstatě jen naše nejbližší okolí

4 Vera Rubin and Dark Matter. In Soter, S. - Tyson, N. (eds.). Cosmic Horizons: Astronomy at the cutting edge. American Museum of Natural History [on-line, cit. 26. 4. 2018]. Dostupné z <https://www.amnh.org/explore/resource-collections/cosmic-horizons/profile-vera-rubin-and-dark-matter/>. OVERBYE, Dennis. Vera Rubin, 88, Dies; Opened Doors in Astronomy, and for Women. The New York Times 2016, Dec. 27 [on-line, cit. 1. 4. 2019]. Dostupné z <https://www.nytimes.com/2016/12/27/science/vera-rubin-astronomist-who-made-the-case-for-dark-matter-dies-at-88.html?_r=0>. 
v rámci Galaxie. A dnes je extrapolována na celý vesmír - není tedy právě tato extrapolace neoprávněným krokem, a tím i zdrojem všech nesrovnalostí $\mathrm{s}$ temnou hmotou? A co je vlastně větším problémem? Nutnost vypořádat se s jednou entitou navíc, nebo nutnost přestavět současnou fyziku? Odpovědět naprosto nezaujatě na tyto otázky je stále problémem, nebot existuje řada argumentů pro i proti existenci temné hmoty, a pokud se tedy někdo staví na obranu jedné $\mathrm{z}$ verzí, bude mít pravděpodobně ještě i jiné než čistě faktické důvody. ${ }^{5}$

V historii moderní fyziky, zdá se, převažují řešení, která se ubírají cestou úpravy teorií, byt se tyto doposud skvěle osvědčily. Newtonova teorie gravitace konfrontována s vysokými rychlostmi nebo silnou gravitací není zachráněna postulováním nové entity, ale je omezena její platnost a je nahrazena speciální a obecnou teorií relativity. OTR konfrontována s extrémní gravitací zřejmě čeká podobný osud. Standardní kosmologický model je upravován téměř permanentně. To by nás mělo smířit se situací, kdy jsou upravovány teorie, o nichž si myslíme, že na nich stojí náš svět a že jejich změna, či dokonce nahrazení teorií novou bude mít dalekosáhlé důsledky.

A když se podíváme do následující tabulky, jak dopadla vybraná ad hoc vysvětlení, nezdá se, že by nám zůstávalo mnoho důvodů věřit, že temná hmota a energie se připojí k Neptunu a pozitronu jako úspěšné předpovědi nových entit. Ovšem statistika z této tabulky nebo snad teze filosofie vědy nejsou pro vědu ničím závazným. Rozhodnou další pozorování.

Přijmeme-li výše uvedené hledisko, že v případě subatomárních částic je spíse normální, že nové částice jsou nejdříve předpokládány, dopočítány, odvozeny a teprve následně potvrzeny pozorováním, případně pozorování a jeho interpretace hypotetickou částicí splývají v jedno, a necháme tak tento svět vymykající se lépe pochopitelnému makrosvětu stranou, zůstane nám jako jediný pozitivní případ ad hoc/vypočítaného elementu a následně skutečně potvrzeného pozorováním pouze Neptun. Možná se k němu přidá v nedaleké budoucnosti jeho př́ibuzná, planeta Devět. Ostatní ad hoc hypotézy byly nakonec opuštěny a řešením byla modifikace teorie. Ano, pokud

5 DOKKUM van, Pieter - DANIELI, Shany - COHEN, Yotam et al. A galaxy lacking dark matter. Nature 2018, 555(1), s. 629-632 [on-line, cit. 10. 4. 2018]. Dostupné z <https://www. nature.com/articles/nature25767>. KULHÁNEK, Petr. Temná hmota nám přichystala další záhadu. Aldebaran Bulletin 2017, 15(10) [on-line, cit. 10. 4. 2018]. Dostupné z <http:// www.aldebaran.cz/bulletin/2017_10_dma.php>. KROUPA, Pavel. 2×10 argumentů proti existenci záhadné temné hmoty. YouTube 2017, 7. 12. [on-line, cit. 10. 4. 2018]. Dostupné $\mathrm{z}\langle$ https://www.youtube.com/watch?v=Az0Sm7dqNdY〉. 


\begin{tabular}{|c|c|c|}
\hline \multirow[t]{2}{*}{ Pozorování/zjištění } & \multicolumn{2}{|c|}{ Vysvětleno } \\
\hline & změnou teorie & doplněním/opuštěním entity \\
\hline Vzájemný pohyb těles & princip (optické) relativity & $\begin{array}{l}\text { přirozená místa, preference- } \\
\text { klidu }\end{array}$ \\
\hline Pád těles & $\begin{array}{l}\text { zákon volného pádu; } \\
\text { teorie gravitace }\end{array}$ & těžké a lehké živly \\
\hline $\begin{array}{l}\text { Kruhové pohyby nebeských } \\
\text { těles }\end{array}$ & Keplerovy zákony & éter \\
\hline Hoření/dýchání & oxidačně-redukční reakce & flogiston \\
\hline Tepelná výměna & $\begin{array}{l}\text { kinetická teorie tepla, ter- } \\
\text { modynamika }\end{array}$ & kalorikum \\
\hline $\begin{array}{l}\text { Pohyb a světlo, koncepce } \\
\text { světla }\end{array}$ & speciální teorie relativity & éterová hypotéza \\
\hline Pohyby Uranu & - & Neptun \\
\hline Stáčení perihélia Merkuru & obecná teorie relativity & Vullán \\
\hline Diracovy rovnice & - & existence pozitronu \\
\hline Dynamický/statický vesmír & Velký třesk & steady state-tvorícípole \\
\hline $\begin{array}{l}\text { Rotační rychlosti vnějších } \\
\text { oblastí galaxií }\end{array}$ & ? & temná hmota (?) \\
\hline Zrychlování rozpínání & $?$ & temná energie (?) \\
\hline $\begin{array}{l}\text { Pohyby transneptunických } \\
\text { těles }\end{array}$ & neuvažuje se & planeta Devět (?) \\
\hline
\end{tabular}

by to měl podobně platit i do budoucna, modifikována by měla být samotná obecná teorie relativity. Ostatně od doby formulace kvantové mechaniky se čas od času objeví konstatování, že OTR má k Newtonově teorii gravitace blíže než ke kvantové mechanice, a že je tedy stále spíše teorií klasickou stejně jako teorie Newtonova. A tak poučeni (?) dějinami můžeme netrpělivě vyhlížet kvantovou teorii gravitace, nebo dokonce nějakého zcela nového následníka, třeba v podobě jednotné teorie, který usedne na fyzikální trůn.

\section{prof. PhDr. Josef Krob, CSc.}

Katedra filozofie, Filozofická fakulta, Masarykova univerzita

Arna Nováka 1, 60200 Brno, Česká republika

jokr@phil.muni.cz 
